Article

\title{
Analysis of Professionals' and the General Public's Perceptions of Passive Houses in Korea: Needs Assessment for the Improvement of the Energy Efficiency and Indoor Environmental Quality
}

\author{
Joohyun Lee $^{1, * \mathbb{C}}$, Mardelle McCuskey Shepley ${ }^{2} \mathbb{( D}$ and Jungmann $\mathrm{Choi}^{3}$ \\ 1 Sustainability R\&D Center, Chungyeon, Seoul 06248, Korea \\ 2 Department of Design and Environmental Analysis, Cornell University, Ithaca, NY 14853, USA; \\ mms449@cornell.edu \\ 3 ZARIN ENC Architects, Passive House Institute Korea, Seoul 05520, Korea; izzarder@gmail.com \\ * Correspondence: joohyunlee5@gmail.com; Tel.: +82-10-3283-2154
}

check for

updates

Citation: Lee, J.; Shepley, M.M.; Choi, J. Analysis of Professionals' and the General Public's Perceptions of Passive Houses in Korea: Needs Assessment for the Improvement of the Energy Efficiency and Indoor Environmental Quality. Sustainability 2021, 13, 8892. https://doi.org/ $10.3390 /$ su13168892

Academic Editor: Vincenzo Costanzo

Received: 5 July 2021

Accepted: 5 August 2021

Published: 9 August 2021

Publisher's Note: MDPI stays neutral with regard to jurisdictional claims in published maps and institutional affiliations.

Copyright: (c) 2021 by the authors. Licensee MDPI, Basel, Switzerland. This article is an open access article distributed under the terms and conditions of the Creative Commons Attribution (CC BY) license (https:// creativecommons.org/licenses/by/ $4.0 /)$.

\begin{abstract}
Despite the economic and environmental benefits of passive houses, their market penetration has been low, which is partially due to misperceptions regarding their cost. This study examined the perceptions of building-related professionals and the general public regarding Korean passive houses to explore strategies for spurring passive house concepts and practices. The participants took an online survey on their interest in and reasons to reside in passive houses and their expected construction costs. The results from two separate groups of participants, including 162 professionals and 130 members of the general public, were analyzed using descriptive and inferential statistics. Both the professional and general public groups expressed a strong interest in passive houses because of the comfortable and healthy indoor environment, energy efficiency, cost savings, and sustainability that they provide. However, the expected construction costs of passive houses were perceived differently by the two groups: They were believed to be less expensive by the professionals and more expensive by the public respondents. This difference seems to result from their prior knowledge or experience regarding passive houses. Both groups were willing to pay more and assumed that the high expected costs were related to the construction products, systems, and labor costs of passive houses. The results showed that the lack of information or education on passive houses could be a major barrier to accessing passive houses, especially with the general public, while the cost could pose less of a barrier to the overall growth of the Korean passive house market. Further efforts by the government and industry are needed in order to provide more educational programs and to identify and manufacture more reasonably priced construction materials.
\end{abstract}

Keywords: passive house; energy efficiency; perception; barriers and opportunities

\section{Introduction}

Global climate change and findings about carbon emissions relating to building energy use have raised environmental concerns and, thereby, given a significant boost to energy efficiency efforts throughout the world [1]. Building energy use accounts for over $40 \%$ of the total primary energy consumption in the U.S. and E.U., and carbon emissions in the building sector make up almost $30 \%$ of global $\mathrm{CO}_{2}$ emissions [2]. Korea, specifically, recorded a higher growth in building sector emissions per capita between 2014 and 2019 [3]. Given this, the need for built environments that help mitigate climate change is more urgent than ever. However, how can the improvement of energy efficiency help buildings to use less energy, thus enabling the reduction of $\mathrm{CO}_{2}$ emissions? This study contributes to the body of knowledge regarding energy-efficient buildings by investigating professionals' and potential residents' perceptions of passive houses and by proposing actions to spur passive house concepts and practices. This topic deserves investigation, as it highlights issues 
regarding the market for energy-efficient homes by examining the end user's expectations and better understanding their economic perspectives.

The Korean building sector, which is the focus of this research, used $38.6 \%$ of the total national energy consumption in 2015 and contributed to higher levels of greenhouse gas (GHG) emissions [2]. In particular, residential buildings accounted for $48 \%$ of the total national building energy consumption, and about $70 \%$ of such energy was used for heating [4]. Eliminating GHG emissions and reducing the global average temperature have been internationally endorsed since the Paris Agreement [5], in which Korea was a participant. The Korean government has set targets to reduce the business-as-usual (BAU) emissions of 850.8 metric tons of carbon dioxide equivalent $\left(\mathrm{MtCO}_{2} \mathrm{e}\right)$ by $32.5 \%$ in 2030 . For the building sector, the current $\mathrm{CO}_{2}$ emissions are $197.2 \mathrm{MtCO}_{2} \mathrm{e}$, with a goal of a $32.5 \%$ reduction by 2030 [6]. In a similar vein, a number of countries and organizations have tried to reduce building energy consumption by implementing innovative sustainable design strategies and generating renewable energy on/off site [7-10]. The Korean public and private building sectors have also focused on building energy efficiency in order to achieve the governmental green building policy of "Low Carbon, Green Growth." The Korean government has initiated strict building energy efficiency requirements for newly constructed buildings, as well as minimum energy efficiency improvements for existing ones [11]. The main drive for the implementation of green buildings in Korea is the Green Buildings Construction Support Act of 2012 of the Ministry of Land, Infrastructure, and Transportation (MOLIT) on the energy performance of buildings [12]. The policy is a combination of a legislation system and a political structure. Korean building energy policy models typically use a top-down approach to sustainable development.

In line with the successful implementation of the green building policy, the Korean government has pursued other energy-efficient building policies, such as the Zero-Energy Buildings (ZEBs) policy. According to the MOLIT, public authorities that occupy and own new buildings should ensure nearly ZEBs by the end of 2020, owners of new private buildings should achieve ZEBs by 2025, and existing buildings should be ZEBs by 2030 . The MOLIT defines a ZEB as a nearly zero-energy building with very high energy performance and the utilization of renewable energy resources generated on the site [13]. This concept is similar to those implemented by other countries [10,14]. The government's green building policy has mainly focused on public buildings and multi-family residential buildings, and it has authorized green building certification systems to further promote building energy efficiency.

Public and large-sized private buildings in Korea are required to implement certain levels of certification. For private sectors, however, the government has not provided enough incentives to promote and support sustainable efforts. Almost $80 \%$ of Korean buildings are privately owned, and $64 \%$ of such buildings are residential [15]. More than half of the residential buildings were built before the introduction of energy efficiency codes and standards, and the majority of them are not sufficiently energy efficient. A total of $37.1 \%(2,666,723)$ of the Korean buildings $(7,191,912)$ were built in the 1980 s or earlier. The Building Energy Efficiency Code for new buildings was initiated in 2010, and the energy consumption of pre-2010 buildings is higher than that of those that were constructed afterwards. In particular, the energy consumption of residential buildings varied significantly before and after 2010, including that of single-family and small multifamily houses (less than three floors and 19 units with a total floor area of $660 \mathrm{~m}^{2}$ ). These houses show energy inefficiency in heating and cooling, as well as low levels of comfort and indoor environmental quality [16]. As shown in Figure 1, the government has operated various building energy acts, codes, and certifications. For example, all new public and private buildings need to comply with the Building Energy Efficiency Code when they have heating and cooling areas that are larger than $500 \mathrm{~m}^{2}$. Different certification schemes apply to different buildings depending upon the gross floor area (GFA). The following examples are shown in Figure 1: Building Energy Efficiency Rating (BEER) (GFA $\geq 3000 \mathrm{~m}^{2}$ ), Green Standard for Energy and Environmental Design (G-SEED) (GFA $\geq 3000 \mathrm{~m}^{2}$ ), or ZEB 
(GFA $\geq 1000 \mathrm{~m}^{2}$ ). The government provides structural and financial incentives, such as density and height bonuses and tax credits, to buildings that achieve certain levels of certification (i.e., Platinum or Gold).

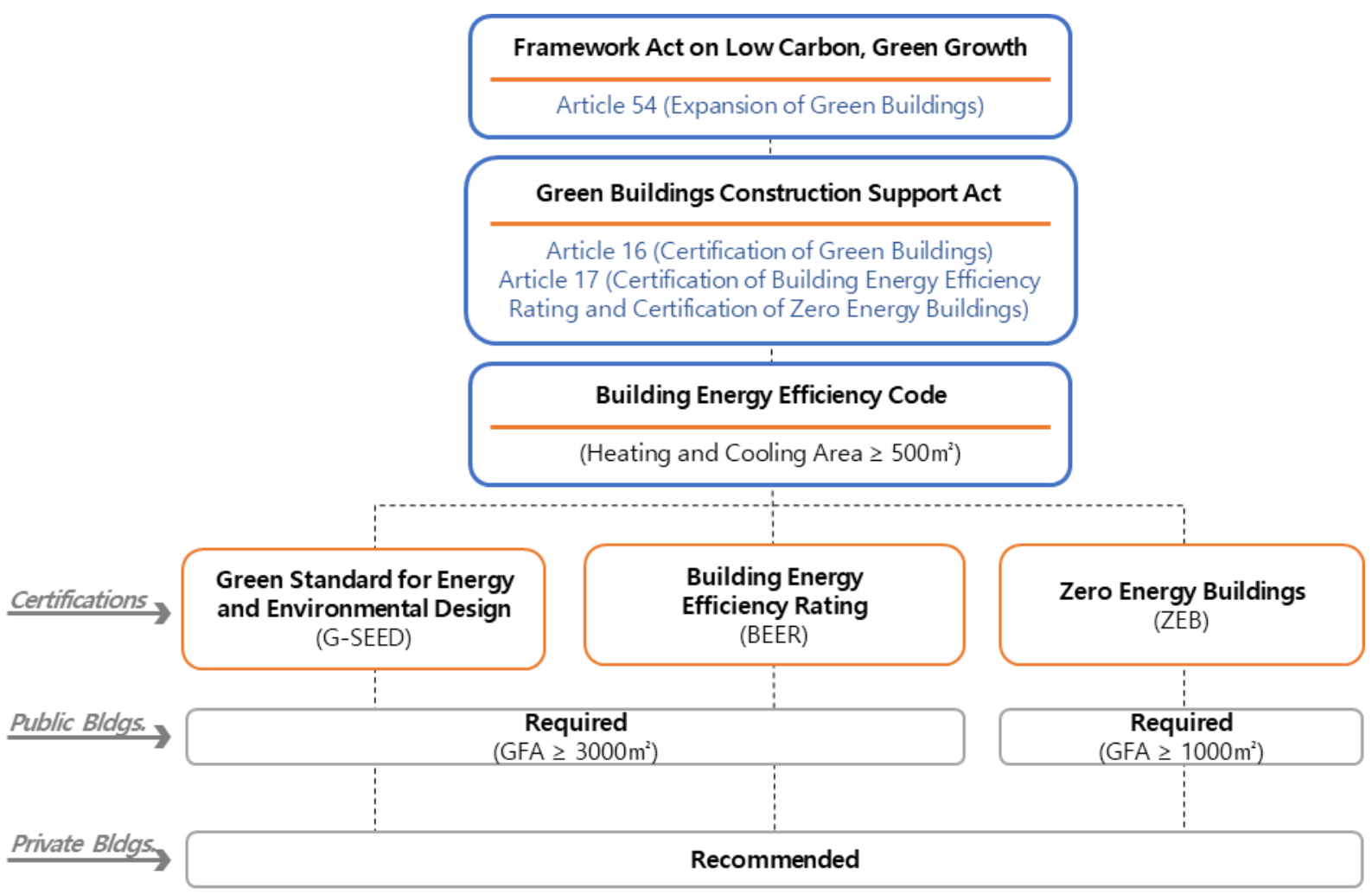

Figure 1. Korean building energy efficiency acts, codes, and certifications.

The Green Remodeling (GR) program provides existing public buildings with technical and financial support to increase building energy efficiency [12]. The G-SEED added the green remodeling evaluation criteria in 2016. Considering that the number of existing buildings surpasses that of new construction projects, making them more efficient is one of the easier ways to meet the governmental building energy efficiency goals in order to reduce carbon emissions and conserve resources. According to the MOLIT, 12,708 projects have participated in G-SEED, of which 48 houses $(1.09 \%)$ were certified between 2002 to 2019 [17]. In addition, the certified BEER buildings number 3081, and 49.2\% of them are residential apartments [18]. Small-sized residential buildings with heating and cooling areas of $500 \mathrm{~m}^{2}$ or less are excluded from the certification and other building energy policies, except for deductions on interest home remodeling loans that are supported by the Green Remodeling program. There is less motivation for paying for the expenses for building energy efficiency policies and certifications (e.g., certification fees: USD 500 to 1800 according to size) [19]. Achieving the national-level efficiency targets is the most challenging task for privately owned single houses. As building energy efficiency policies focus on public buildings or large-scale buildings, the aging of small-sized residential structures is a serious concern with respect to increasing the building energy performance.

Given this situation, private building sectors have tried to build more energy-efficient houses, which are known as Korean Passive Houses (KPHs), in line with the government's building policies. The Passive House Institute of Korea (PHIKO) has led one of the movements in the private sector [20], and in the early 2000s, the institute developed Korean prototypes. The KPHs modified the German Passive House [21] to accommodate differences in climates, building materials, and construction technologies particular to Korea. A German Passive House requires less than $15 \mathrm{kWh} / \mathrm{m}^{2}$ for heating and cooling and 
has high levels of insulation and very low infiltration ( $\mathrm{n} 50=0.6 / \mathrm{h})$ [22]. It is expected that the market for KPHs will keep growing in the coming years. Figure 2 demonstrates that the number of certified Korean Passive Houses has steadily increased since 2009, up to a total of 462 as of December 2019 [23]. The expansion in 2019 coincided with the completion of the first passive house complexes in Korea. A total of 60 households were built in Sejong-si, while 238 were built in Gyeonggi-do [24]. The growth began from a very low point and increased rapidly due to the construction of a couple of large developments.

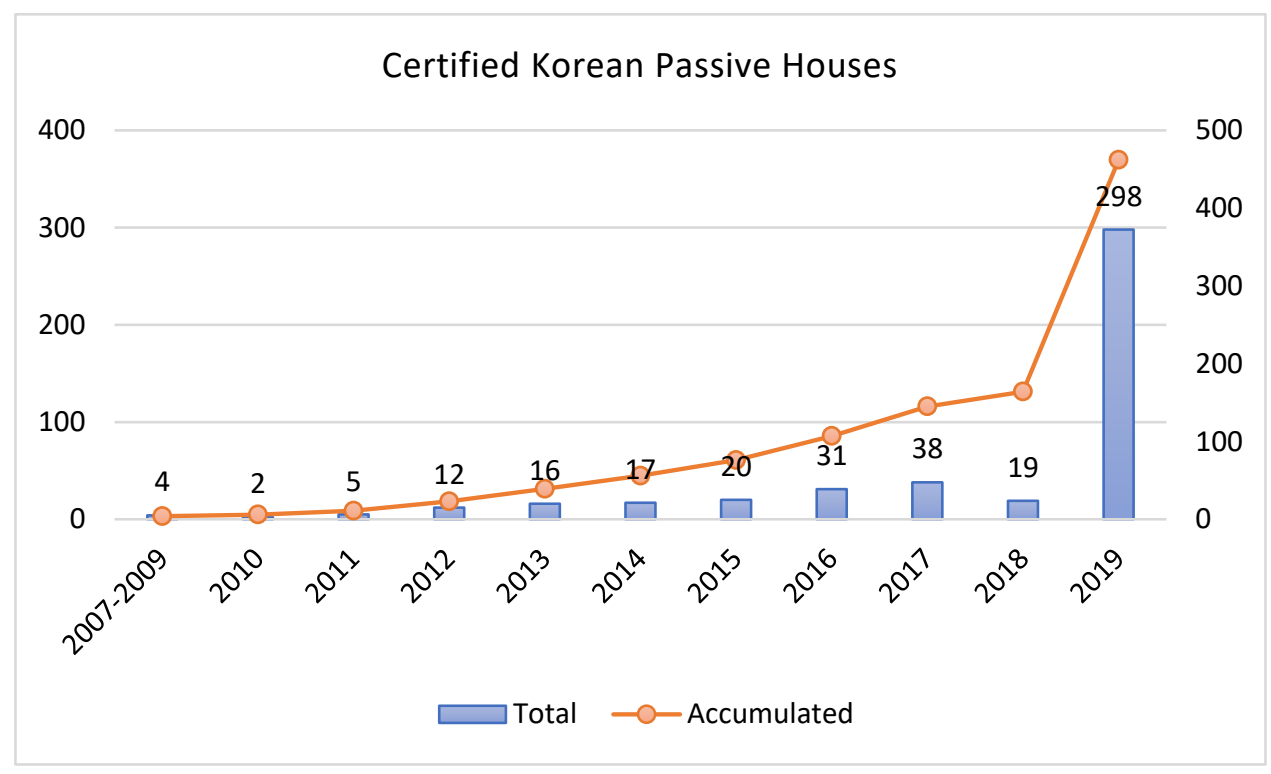

Figure 2. The number of certified passive houses in Korea (2007-2019) (Source: PHIKO).

The passive house has been an important driver behind the concept of the lowenergy house. One difference is that the $\mathrm{KPH}$ requires less than $50 \mathrm{kWh} / \mathrm{m}^{2}$ for energy consumption to prevent winter overheating due to the ondol (traditional Korean underfloor heating system). The ondol heats up the room with pipes that are installed in the floor; heated water flows from the boiler, unlike in many Western homes, which use a furnace or boiler to distribute heated air through ductwork. The Western type does not operate by heating indoor air. In underfloor heating systems, water or a water-glycol solution is heated. Overheating can become a risk on warmer and sunnier winter days. If a German Passive House (less than $15 \mathrm{kWh} / \mathrm{m}^{2}$ ) were to be built in Korea, it would not have an ondol space-heating system installed, since it would overheat on winter mornings when the ondol would release heat into the house and receive solar heat from south-facing windows.

While the number of passive houses in Korea is still very low, the market for these homes is expected to grow significantly. The benefits of low-energy/passive building designs include energy savings, cost reductions, a higher quality of design, and improved environmental conditions and comfort [25-30]. For example, the PHI (Passive House Institute) and PHIUS (Passive House Institute US) report overall energy savings of $60-70 \%$ and a $90 \%$ improvement in heating energy consumption as compared to the consumption in typical buildings [21,31]. In passive houses, for better performance and user satisfaction, design strategies that are specific to different climate zones are required $[32,33]$. In the early stages of passive house design, architects' roles were crucial when dealing with energy-efficient houses [34], as the houses had to be designed to allow the passive design and systems to work together right from the start. In some studies, passive house residents showed high satisfaction with comfortable indoor conditions while using less energy $[35,36]$. Their better efficiency is derived from long-term relationships with users, and the performance outcomes bring higher-quality designs and greater robustness. However, most people rarely consider the energy efficiency of residential buildings due to misunderstandings regarding the price that these benefits carry [37,38]. Neither professionals nor 
users are knowledgeable about how much it costs to build a low-energy/passive house [39]. These misperceptions have prevented professionals and users from acting in their own long-term interests.

In addition, professionals and non-professionals have shown increased interest in indoor air quality due to outdoor sources that have been compromised, such as with pollution from traffic, construction, combustion sources, and particulate matter. They have expressed concern about indoor air quality, including issues related to off-gassing from building materials and internally generated pollutants [40]. According to some authors, the benefits of passive houses are related to wellbeing and internal comfort [41,42]. Researchers and organizations have stated that appropriate mechanical ventilation systems and increased air flow can improve indoor air quality when external air quality parameters are poor $[43,44]$. Additionally, advanced and efficient HVAC systems can offer energy savings and benefits to occupants $[45,46]$. Air quality impacts the health and comfort of building occupants [47], and passive houses have higher air-change rates than that of the minimum building code requirement and achieve limited energy consumption [48-51]. This could become a driving force for increased competitiveness through approaches to implementation for sustainable growth.

This study advocates for increasing the number of passive houses in Korea based on the positive responses of professionals and the general public regarding building or living in passive houses. Possible barriers against adopting passive houses are also explored. Despite the economic and environmental benefits of passive houses, their penetration into the market has been low, which is partially due to outdated perceptions of their incremental cost [34]. These old-fashioned perceptions can "prevent further advancement and mainstream adoption of the high-performance home technologies and systems for both new and existing homes" [52]. This study is significant, as it is one of the first attempts to identify related perceptions regarding passive houses in Korea. It aims to better understand how design practitioners and the general public perceive the issues associated with passive houses in Korea, including those relating to cost and expectations. As previous researchers have noted, there has been a need for greater understanding of professionals' and clients' concepts regarding the construction of passive houses. Little attention has been paid to detailed investigations of the perspectives of clients or end users, while much focus has been given to those of professionals [25]. This study will provide meaningful support for the importance of communication and collaboration between professionals and end users.

\section{Methods}

This research focuses on perceptions of passive houses in Korea. We employed several methods, including a dense literature review, online surveys, and focus group interviews with professionals and members of the general public who showed an interest in passive houses (Figure 3). The professionals included architectural practitioners and architecture students. A survey is a well-established research method that allows researchers to collect information "from a sample of individuals through their responses to questions" on a wide range of issues including attitudes, human behaviors, and perspectives ([53], p. 160). By asking open-ended questions in the focus interviews, this study intended to further explore the research participants' opinions on the given topic in their own words. As a qualitative approach, focus group interviews enable researchers to interview a group of participants together and obtain in-depth understanding of the research topic. With a more integrative research approach, the current study combined multiple data sources to "provide appropriate checks against the weak points in each and enable the benefits to complement each other" $[54,55]$. 


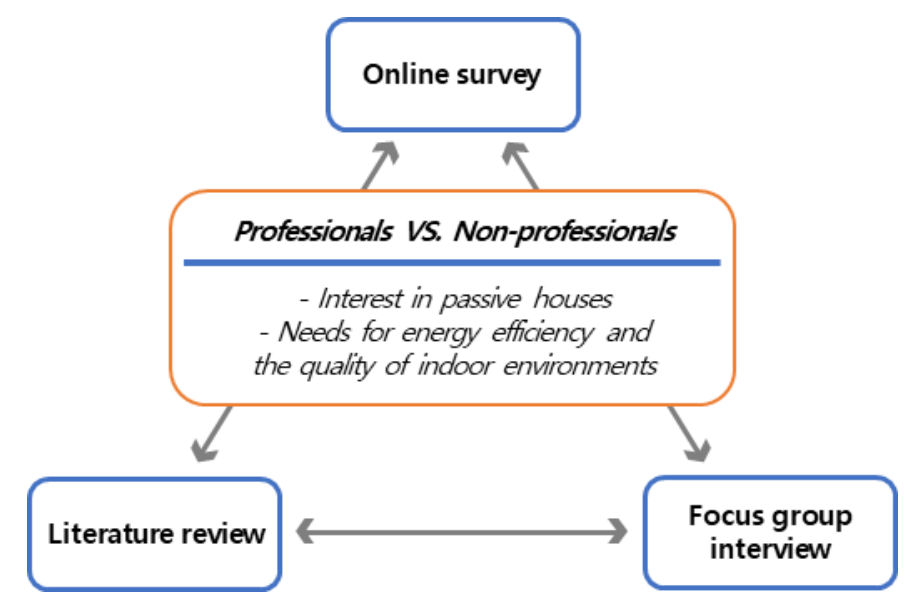

Figure 3. Triangulation of the research method.

The quantitative portion of this research consisted of a broad-based sample representing building-related professionals (e.g., designers, builders, contractors, or engineers) and members of the general population who had lived in or showed interest in passive houses. A total of 16 questions were used to investigate the participants' perceptions of passive houses in terms of barriers, potential benefits, and their personal characteristics. Three questions were open-ended, and the others were dichotomous measures (e.g., yes/no and know / do not know), multiple choice, or checkboxes for selecting all that applied. Each question had "other" textboxes for closed-ended questions, which allowed the respondents to either offer additional information about their choices or provide alternative answers. In addition, open-ended questions had comment fields that asked respondents to enter their answers with a 150-character limit. The online survey questions are described in Table 1. To help the participating subjects better understand the questionnaire, some of the technical terms were translated into layperson's terms. The survey results were collected from 292 adults who were aged 18 to 80 years over six months from December 2019 to May 2020. It generally took about $10-15 \mathrm{~min}$ to complete the survey. We recruited the professionals and members of the general public who had participated in passive house seminars and educational events, such as passive house open days, in which building owners opened their doors to allow participants to visit and experience their certified passive houses. We provided the participants with an information sheet asking them to participate in a web-based online survey.

The qualitative portion of the study explored a broad and diverse set of voices from the subjects regarding passive houses. This part of the research included three focus group interviews (professional, general, and student groups) to get diverse points of view. The interviews were intended to gather additional opinions that were not covered in the questionnaire. At the end of the initial online survey, the participants were given information on the purpose and procedures of the separate focus group interviews and on how to contact the research team.

To analyze the collected data, different statistical methods were used, including descriptive statistics and independent-sample t-tests, with the Statistical Package for the Social Sciences (SPSS) software package. For the open-ended questions and interviews, we used a coding process to group similar answers together and analyze the responses by using proportions and comparisons against other variables in the data. Finally, individual open-ended respondent comments were described in the results. This methodological triangulation involved the use of various data collection methods, thereby increasing the credibility and validity of the research [54]. 
Table 1. Survey questionnaire.

\begin{tabular}{|c|c|}
\hline \multicolumn{2}{|r|}{ Questions } \\
\hline Personal characteristics & Job, sex, age, education, and income \\
\hline Interest in passive houses & $\begin{array}{l}\text { Q1. How familiar are you with passive houses? } \\
\text { Q1-1. Where did you get information/knowledge about passive houses? } \\
\text { (Select all that apply) } \\
\text { Q1-2. Have you lived in a passive house? } \\
\text { Q1-3. Do you plan to build/live in a passive house? } \\
\text { Q2. Why are you interested in passive houses? (Select all that apply) }\end{array}$ \\
\hline $\begin{array}{l}\text { Expected cost and the reasons for } \\
\text { expensiveness }\end{array}$ & $\begin{array}{l}\text { Q3. Do you agree that it costs more to build a passive house than a } \\
\text { conventional equivalent? } \\
\text { Q3-1. How expensive is it to build a passive house compared to a conventional one? } \\
\text { Q3-2. Why do you think passive houses are more expensive to build? (Open-ended) }\end{array}$ \\
\hline $\begin{array}{l}\text { Affordable cost and reasons for living an } \\
\text { expensive passive house }\end{array}$ & $\begin{array}{l}\text { Q3-3. Do you still want to build a passive house though its up-front cost is more than } \\
\text { that of a conventional house? } \\
\text { Q3-4. How much of an increase do you still accept when building a passive house? } \\
\text { Q3-5. Why do you want to live in a passive house? (Open-ended) }\end{array}$ \\
\hline
\end{tabular}

\section{Results}

\subsection{Characteristics of Respondents}

The background of the participants was analyzed descriptively. The subjects represented various demographics in their occupation, sex, age, education, and income. Detailed characteristics are described in Table 2. The survey results were analyzed in two groups: 162 building-related professionals (55.5\%) and 130 members of the public (non-buildingrelated professionals) $(44.5 \%)$. The number of professionals was about $20 \%$ higher than that of the public participants. The professional group had an overwhelmingly higher ratio of males $(48.6 \%)$ than females $(6.8 \%)$, while the general group had a ratio of 3:1. More than half of the group ranged from 40 to 50 years old $(57.5 \%)$. The statistical analysis showed differences in gender $(\mathrm{t}(290)=-3.363, p=0.001)$ and age group $(\mathrm{t}(290)=3.041, p=0.003)$ between the professionals and the general public who participated in the survey. More than $95 \%$ of all respondents had college or higher-education degrees. The professionals were twice as likely to have graduate-level degrees. The income of $42.0 \%$ of the respondents was over USD 50,000, but there was no significant difference found in the income between the groups $(\mathrm{t}(290)=-1.688, p=0.092)$. According to Statistics Korea, in 2018, about $50 \%$ of 25-64-year-olds in the country held a bachelor's degree or higher with an average income of USD 30,000 [56]; therefore, our study populations had higher education and income levels than those of the general public. The general public participants were considered to be prospective clients that showed an interest in passive houses and that might be willing to build or rent one in a few years. Though passive houses are not widespread in Korea, the public interest found in this study was as high as the interest of the professionals. 
Table 2. Descriptive statistics of the respondents $(n=292)$.

\begin{tabular}{|c|c|c|c|c|c|c|c|}
\hline \multirow{2}{*}{\multicolumn{2}{|c|}{ Questions }} & \multirow[b]{2}{*}{ Professionals } & \multirow[b]{2}{*}{ Public } & \multirow[b]{2}{*}{ Total } & \multicolumn{3}{|c|}{$t$-Test } \\
\hline & & & & & $t$ & d & $\begin{array}{c}\text { Sig } \\
\text { (2-Tailed) }\end{array}$ \\
\hline & Job & $162(55.5 \%)$ & $\begin{array}{c}130(44.5 \%) \\
\text { Office worker: } \\
44(15.1 \%) \\
\text { Self-employed: } \\
16(5.5 \%) \\
\text { Government official: } \\
12(4.1 \%) \\
\text { Housewife: } 7(2.4 \%) \\
\text { Student: } 30(10.3 \%) \\
\text { Other: } 21(7.2 \%)\end{array}$ & $292(100 \%)$ & - & - & - \\
\hline Sex & $\begin{array}{c}\text { Male } \\
\text { Female }\end{array}$ & $\begin{array}{c}142(48.6 \%) \\
20(6.8 \%)\end{array}$ & $\begin{array}{l}94(32.2 \%) \\
36(12.3 \%)\end{array}$ & $\begin{array}{c}236(80.8 \%) \\
56(19.2 \%)\end{array}$ & -3.363 & 290 & 0.001 \\
\hline Age & $\begin{array}{c}20-29 \\
30-39 \\
40-49 \\
50-59 \\
60 \text { and over }\end{array}$ & $\begin{array}{c}6(2.1 \%) \\
30(10.3 \%) \\
71(24.3 \%) \\
42(14.4 \%) \\
13(4.5 \%)\end{array}$ & $\begin{array}{c}30(10.3 \%) \\
29(9.9 \%) \\
30(10.3 \%) \\
25(8.6 \%) \\
16(5.5 \%)\end{array}$ & $\begin{array}{c}36(12.3 \%) \\
59(20.2 \%) \\
101(34.6 \%) \\
67(22.9 \%) \\
29(9.9 \%)\end{array}$ & 3.041 & 290 & 0.003 \\
\hline Education & $\begin{array}{l}\text { High school } \\
\text { Undergraduate } \\
\text { Graduate } \\
\text { Other }\end{array}$ & $\begin{array}{c}6(2.1 \%) \\
91(31.2 \%) \\
65(22.3 \%) \\
0(0.0 \%)\end{array}$ & $\begin{array}{c}4(1.4 \%) \\
95(32.5 \%) \\
30(10.3 \%) \\
1(0.3 \%)\end{array}$ & $\begin{array}{c}10(3.4 \%) \\
186(63.7 \%) \\
95(32.5 \%) \\
1(0.3 \%)\end{array}$ & 2.384 & 290 & 0.018 \\
\hline Income & $\begin{array}{l}\text { Under USD } 30,000 \\
\text { USD } 30,000-40,000 \\
\text { USD } 40,000-50,000 \\
\text { Over USD 50,000 } \\
\text { Other }\end{array}$ & $\begin{array}{c}14(4.8 \%) \\
25(8.6 \%) \\
29(9.9 \%) \\
78(26.7 \%) \\
16(5.5 \%)\end{array}$ & $\begin{array}{c}14(4.8 \%) \\
15(5.1 \%) \\
19(6.5 \%) \\
44(15.1 \%) \\
38(13.0 \%)\end{array}$ & $\begin{array}{c}28(9.6 \%) \\
40(13.7 \%) \\
48(16.4 \%) \\
122(41.8 \%) \\
54(18.5 \%)\end{array}$ & -1.688 & 290 & 0.092 \\
\hline
\end{tabular}

\subsection{Interest in Passive Houses}

More than $95 \%$ of the respondents were considered to have familiarity with passive houses (Table 3). They typically acquired information/knowledge on passive houses from a number of sources, such as from educational seminars/workshops $(48.3 \%)$, the internet (33.6\%), the Korean Passive House homepage (31.8\%), and others, as shown in Table 3. The professionals showed a preference for educational seminars or workshops, while the non-professionals generally used the internet. Only $7.5 \%$ of the subjects had experience with living in a passive house; the number of participants from the general public living in passive houses was slightly higher than that of the professionals, but more than $90 \%$ of both groups showed a willingness to build or rent a passive house in a few years. The percentage of the professionals (51.4\%) that showed a desire to build/live in a passive house was slightly higher than that of the non-professionals (39.0\%), although the number of passive houses in Korea is low.

When the respondents were asked to select reasons for their interest in passive houses, the common choice for both professionals and the public was the comfortable/healthy interior climate $(73.3 \%)$, reduced energy use $(51.0 \%)$, cost savings $(50.3 \%)$, sustainability $(34.2 \%)$, and others $(2.4 \%)$ (Table 3$)$. Between the groups, there were differences in comfortableness $(\mathrm{t}(290)=2.213, p=0.028)$ and cost savings $(\mathrm{t}(290)=-2.262, p=0.024)$. As shown in Table 3, the professionals showed a preference for the comfortable and healthy living environment of passive houses (43.5\%), while the general public considered energy cost savings to be important $(29.8 \%)$. 
Table 3. Interest in passive houses $(n=292)$.

\begin{tabular}{|c|c|c|c|c|c|c|}
\hline \multirow[b]{2}{*}{ Questions } & \multirow[b]{2}{*}{ Professionals } & \multirow[b]{2}{*}{ Public } & \multirow[b]{2}{*}{ Total } & \multicolumn{3}{|c|}{$t$-Test } \\
\hline & & & & $t$ & d & $\begin{array}{c}\text { Sig } \\
\text { (2-Tailed) }\end{array}$ \\
\hline \multicolumn{7}{|l|}{$\begin{array}{c}\text { Q1. How familiar are you with passive } \\
\text { houses? }\end{array}$} \\
\hline Yes & $162(55.5 \%)$ & $117(40.1 \%)$ & $279(95.5 \%)$ & \multirow{2}{*}{-4.228} & \multirow[b]{2}{*}{290} & \multirow[b]{2}{*}{0.000} \\
\hline No & 0 & $13(4.5 \%)$ & $13(4.5 \%)$ & & & \\
\hline \multicolumn{7}{|l|}{$\begin{array}{l}\text { Q1-1. Where did you get } \\
\text { information/knowledge about passive } \\
\text { houses? (Select all that apply) }\end{array}$} \\
\hline Passive house homepages & $56(19.2 \%)$ & $37(12.7 \%)$ & $93(31.8 \%)$ & 1.112 & 290 & 0.267 \\
\hline Education/Seminar & $91(31.2 \%)$ & $50(17.1 \%)$ & $141(48.3 \%)$ & 3.047 & 290 & 0.003 \\
\hline Internet & $44(15.1 \%)$ & $54(18.5 \%)$ & $98(33.6 \%)$ & -2.607 & 290 & 0.010 \\
\hline Book/Magazine/Newspaper & $27(9.2 \%)$ & $26(8.9 \%)$ & $53(18.2 \%)$ & -0.733 & 290 & 0.464 \\
\hline TV/Radio & $6(2.1 \%)$ & $11(3.8 \%)$ & $17(5.8 \%)$ & -1.729 & 290 & 0.085 \\
\hline Friends/Neighbors & $16(5.5 \%)$ & $10(3.4 \%)$ & $26(8.9 \%)$ & 0.650 & 290 & 0.516 \\
\hline Other & $16(5.5 \%)$ & $10(3.4 \%)$ & $26(8.9 \%)$ & 0.650 & 290 & 0.516 \\
\hline \multicolumn{7}{|l|}{ Q1-2. Have you lived in a passive house? } \\
\hline Yes & $10(3.4 \%)$ & $12(4.1 \%)$ & $22(7.5 \%)$ & \multirow{2}{*}{-1.232} & \multirow{2}{*}{287} & \multirow{2}{*}{0.219} \\
\hline No & $152(52.1 \%)$ & $118(40.4 \%)$ & $272(92.5 \%)$ & & & \\
\hline \multicolumn{7}{|l|}{$\begin{array}{l}\text { Q1-3. Do you plan to build/live in a passive } \\
\text { house? }\end{array}$} \\
\hline Yes & $150(51.4 \%)$ & $114(39.0 \%)$ & $264(90.4 \%)$ & \multirow{3}{*}{-1.413} & \multirow{3}{*}{290} & \multirow{3}{*}{0.159} \\
\hline No & $11(3.8 \%)$ & $14(4.8 \%)$ & $25(8.6 \%)$ & & & \\
\hline No response & $1(0.3 \%)$ & $2(0.7 \%)$ & $3(1.0 \%)$ & & & \\
\hline \multicolumn{7}{|l|}{$\begin{array}{l}\text { Q2. Why are you interested in passive } \\
\text { houses? (Select all that apply) }\end{array}$} \\
\hline Comfortable/Healthy & $127(43.5 \%)$ & $75(25.7 \%)$ & $202(69.2 \%)$ & 2.213 & 290 & 0.028 \\
\hline Reducing energy use/Energy efficiency & $75(25.7 \%)$ & $74(25.3 \%)$ & $149(51.0 \%)$ & -1.089 & 290 & 0.071 \\
\hline Energy cost savings & $72(24.7 \%)$ & $87(29.8 \%)$ & $159(54.5 \%)$ & -2.262 & 290 & 0.024 \\
\hline \multirow{2}{*}{$\begin{array}{c}\text { Sustainable/Preserving the planet/Reducing } \\
\text { carbon footprint } \\
\text { Other }\end{array}$} & $50(17.1 \%)$ & $50(17.1 \%)$ & $100(34.2 \%)$ & \multirow[t]{2}{*}{-1.359} & \multirow[t]{2}{*}{290} & \multirow[t]{2}{*}{0.076} \\
\hline & $5(1.7 \%)$ & $2(0.7 \%)$ & $7(2.4 \%)$ & & & \\
\hline
\end{tabular}

In order to examine the differences between the professionals and the public, the openended answers were grouped to compare the perceptions. The results showed that the subjects responded to increased demands for healthy and efficient homes that far exceeded the minimum standards of building codes. This finding corresponds to the results from the focus groups. Below are representative statements from the focus group participants.

Comments from the Professionals

- "The typical Korean home design and construction, I feel, is very clumsy; living efficiency is overlooked, which could be answered with a simple design of space and energy usage."

- "Passive houses have been constructed to the standard and certified with test results. The application of building physics to the houses plays a vital role in striving to improve building performance and indoor quality."

- "Building codes in Korea have been strengthened to deliver energy-efficient and low-impact buildings that provide healthy and comfortable environments to live and work in."

- "Mechanical ventilation and increased infiltration rates are needed when weather and local ambient parameters indicate poor outdoor air, such as yellow dust in spring, particulate pollution in winter, and even the COVID-19 pandemic." 
Comments from the General Public

- "I got interested after visiting a passive house."

- $\quad$ "I think the difference between conventional, especially apartments, and passive houses is that they are ready-made and tailored (custom design)."

- "Always interested in design and performance, particularly innovative architecture like this [passive house]."

- "The passive house is a well-insulated house with no condensation."

- "I became interested in passive houses after watching a TV show, since they seemed easy to take care of and to provide thermal comfort with minimal energy costs."

\subsection{Expected Costs and the Reasons for Expensiveness}

This study examined the barriers to building a passive house with respect to the expected costs and other reasons for participants to avoid residing in passive houses. More than $95 \%$ of the participants responded that passive houses are expected to cost more up front than their conventional counterparts (Table 4). The participants from the general public estimated that building a passive house was more expensive than the professionals' estimates. Questions were asked about the estimates of the expected costs of building passive versus conventional houses. Approximately $86 \%$ of all the participants (251 out of 292) responded that a passive house would cost $20-50 \%$ more than a conventional one. In particular, the majority of the general public group reported that expected construction costs of a passive house would be $50 \%$ more than the costs of conventional construction, unlike the professionals, who estimated that the costs would be only $20-50 \%$ more. There was a statistically significant difference in the expected prices between the professionals and the public $(\mathrm{t}(290)=-2.703, p=0.007)$.

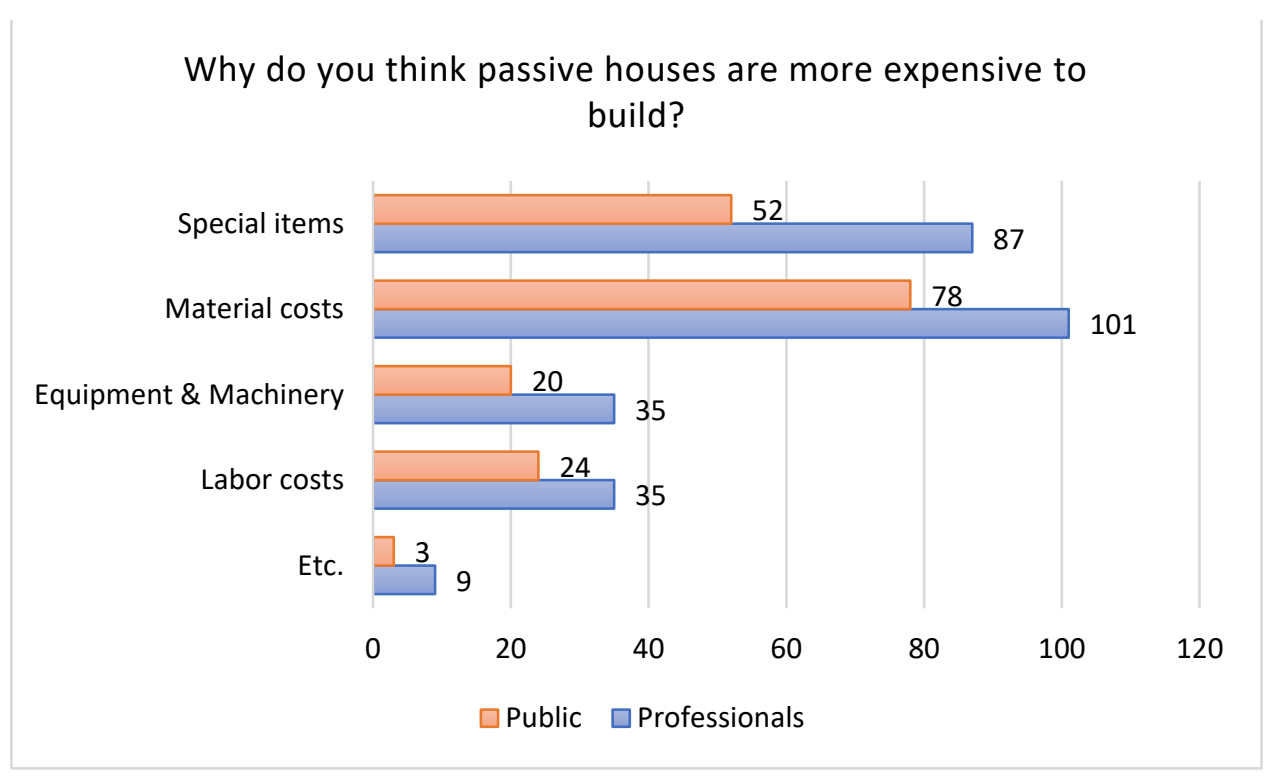

Figure 4. Reasons for the expensiveness of passive houses according to the respondents. 
Table 4. Expected costs and the reasons for expensiveness $(n=292)$.

\begin{tabular}{|c|c|c|c|c|c|c|}
\hline \multirow[b]{2}{*}{ Questions } & \multirow[b]{2}{*}{ Professionals } & \multirow[b]{2}{*}{ Public } & \multirow[b]{2}{*}{ Total } & \multicolumn{3}{|c|}{$t$-Test } \\
\hline & & & & $t$ & d & $\begin{array}{c}\text { Sig } \\
\text { (2-Tailed) }\end{array}$ \\
\hline \multicolumn{7}{|l|}{$\begin{array}{l}\text { Q3. Do you agree that it costs more to build a } \\
\text { passive house compared to a conventional } \\
\text { equivalent? }\end{array}$} \\
\hline Yes & $157(53.8 \%)$ & $121(41.4 \%)$ & $278(95.2 \%)$ & \multirow[b]{2}{*}{-1.526} & \multirow[b]{2}{*}{290} & \multirow[b]{2}{*}{0.128} \\
\hline No & $5(1.7 \%)$ & $9(3.1 \%)$ & $14(4.8 \%)$ & & & \\
\hline \multicolumn{7}{|l|}{$\begin{array}{l}\text { Q3-1. How expensive is it to build a passive } \\
\text { house compared to a conventional one? }\end{array}$} \\
\hline$\leq 20 \%$ & $30(10.3 \%)$ & $18(6.2 \%)$ & $48(16.4 \%)$ & \multirow{6}{*}{-2.703} & \multirow{6}{*}{290} & \multirow{6}{*}{0.007} \\
\hline $30 \%$ & $58(19.9 \%)$ & $36(12.3 \%)$ & $97(33.2 \%)$ & & & \\
\hline $40 \%$ & $13(4.5 \%)$ & $9(3.1 \%)$ & $22(7.5 \%)$ & & & \\
\hline $50 \%$ & $48(16.4 \%)$ & $39(13.4 \%)$ & $84(28.8 \%)$ & & & \\
\hline$\geq 100 \%$ & $9(3.1 \%)$ & $18(6.2 \%)$ & $27(9.2 \%)$ & & & \\
\hline Other & $4(1.4 \%)$ & $10(3.4 \%)$ & $14(4.8)$ & & & \\
\hline $\begin{array}{l}\text { Q3-2. Why do you think passive houses are } \\
\text { more expensive to build? }\end{array}$ & & en-ended & on, comm & found ir & gure 4 & \\
\hline
\end{tabular}

The reported reasons for the expensive construction costs of passive houses are summarized in Figure 4. The respondents' comments were categorized into similar topics, such as the special items needed, increases in material costs, the equipment and machinery required, added labor costs, etc. For example, membranes and tape are essential for airtightness, as they can prevent thermal bypassing and wind washing. These materials influence the thermal performance of the houses. In addition, mechanical ventilation for heat recovery (MVHR) is mandatory for the certification of passive houses, and the windows would need to be at least triple glazed, which costs more than the typical fenestration for code-compliant houses.

The subjects reported that construction costs would increase due not only to materials, but also the labor costs associated with installing the materials. Some professionals mentioned that passive houses are made with the same materials, methodologies, workers, and schedules as non-passive houses, but others emphasized that the installation of airtight membranes is very expensive and often makes clients doubt if they can ever recoup these savings. The professionals stated that their customers also wonder if these membranes are properly installed and working effectively. Another cost issue that was raised was related to the limited economies of scale due to the small market, limited purchasing, and the limited builders and technicians (see Figure 4). The lack of specific building expertise was identified as problematic as well. Finally, the participants concluded that passive houses would require additional expenditures, including those for building performance tests and certification fees.

Some responses explained reasons for the high costs expected for building passive houses compared to non-passive houses.

Comments from Professionals

- "A passive house is not a conventional house and is based on solid science. So, this is not to be compared."

- "Passive houses and conventional houses have totally different building physics. It has been proven through residents' living experiences."

- "Costs have come down as prices for materials have dropped, and contractors have become more familiar with passive-building methods." 
Comments from the General Public

- "A passive house is not expensive because it is a planned, optimized, and verified home with standards."

- "Passive houses require a quality assurance process, such as airtightness tests and certification processes."

- "Building a passive house would be a matter of money, but if it evens out, I would be interested in seeing how long that would actually take."

\subsection{Affordable Costs and Reasons for Living in an Expensive Passive House}

More than $90 \%$ of the respondents indicated that they had a desire to live in a passive house despite the comparison of its initial cost with that of a non-passive one. In terms of increased construction costs, both the professional and the general participants selected less than $20 \%$ (Table 5). The next choice was $30 \%$, which $21 \%$ of the professionals and $15 \%$ of the public chose. Approximately $10 \%$ of the respondents expressed their willingness to accept a passive house construction cost increase of more than $50 \%$ compared with conventional houses. They expected passive house construction to be expensive, but within reason.

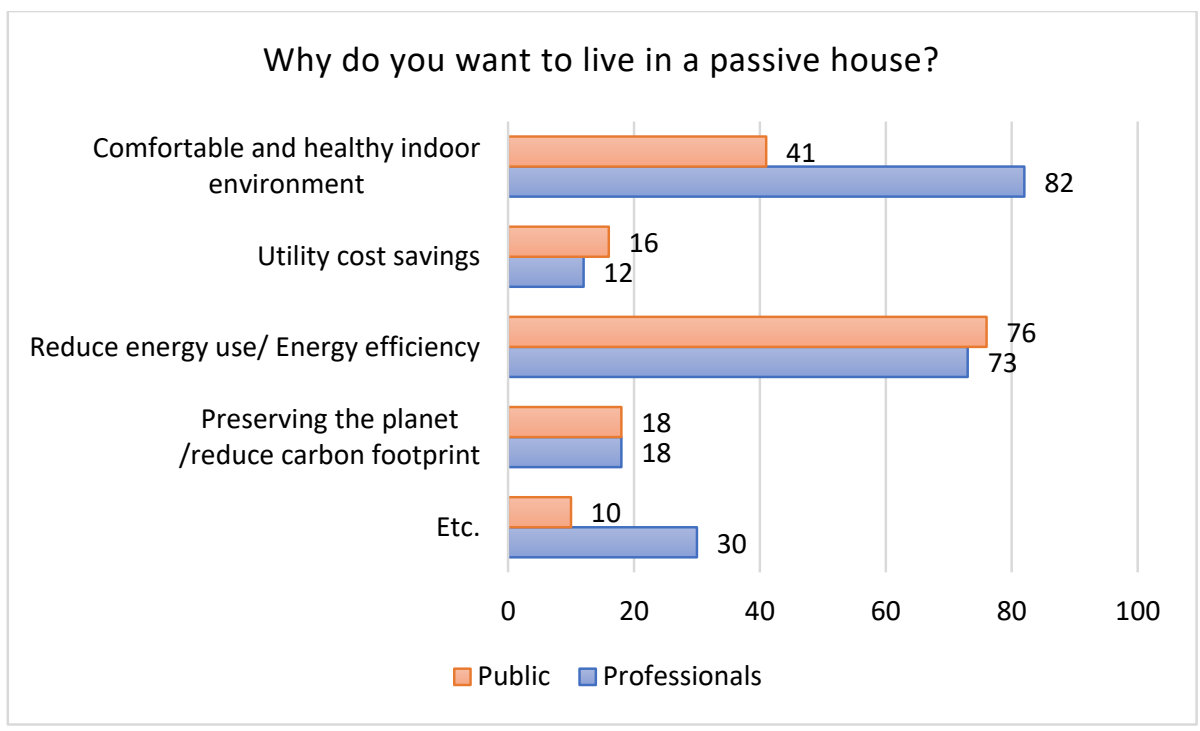

Figure 5. Reasons for living in an expensive passive house.

Table 5. Affordable costs and potential benefits of passive houses $(n=292)$.

\begin{tabular}{|c|c|c|c|c|c|c|}
\hline \multirow[b]{2}{*}{ Questions } & \multirow[b]{2}{*}{ Professionals } & \multirow[b]{2}{*}{ Public } & \multirow[b]{2}{*}{ Total } & \multicolumn{3}{|c|}{$t$-Test } \\
\hline & & & & $t$ & d & $\begin{array}{c}\text { Sig } \\
\text { (2-Tailed) }\end{array}$ \\
\hline \multicolumn{7}{|c|}{$\begin{array}{l}\text { Q3-3. Do you still want to build a passive } \\
\text { house though its up-front cost is more than } \\
\text { that of a conventional house? }\end{array}$} \\
\hline $\begin{array}{l}\text { Yes } \\
\text { No }\end{array}$ & $\begin{array}{c}150(51.4 \%) \\
12(4.1 \%)\end{array}$ & $\begin{array}{c}117(40.1 \%) \\
13(4.5 \%)\end{array}$ & $\begin{aligned} 267 & (91.4 \%) \\
25 & (8.6 \%)\end{aligned}$ & -0.785 & 290 & 0.433 \\
\hline \multicolumn{7}{|c|}{$\begin{array}{l}\text { Q3-4. How much of an increase do you still } \\
\text { accept when building a passive house? }\end{array}$} \\
\hline$\leq 20 \%$ & $74(25.3 \%)$ & $53(18.2 \%)$ & $127(43.5 \%)$ & & & \\
\hline $30 \%$ & $62(21.2 \%)$ & $43(14.7 \%)$ & $105(36.0 \%)$ & & & \\
\hline $40 \%$ & $6(2.1 \%)$ & $5(1.7 \%)$ & $11(3.8 \%)$ & -2.307 & 290 & 0.043 \\
\hline $50 \%$ & $14(4.8 \%)$ & $20(6.8 \%)$ & $34(11.6 \%)$ & -2.307 & 290 & \\
\hline$\geq 100 \%$ & $1(0.3 \%)$ & $1(0.3 \%)$ & $2(0.7 \%)$ & & & \\
\hline Other & $5(1.7 \%)$ & $8(2.7 \%)$ & $13(4.5 \%)$ & & & \\
\hline
\end{tabular}

Q3-5. Why do you want to live in a passive house? 
Figure 5 shows the respondents' reasons for building a passive house despite their high costs. Many professionals were more concerned about comfortable and healthy indoor environments than the general public was, although other items were mentioned with similar frequencies. Both groups indicated that they needed to be convinced of passive houses' effective operation in terms of comfort, health, profitability, and energy results. The professionals placed more value on the quality of life rather than on the cost. They expected the technology and innovation of passive houses, with their verifiable quality assurance procedures, to be the most important parts of improved living conditions. The professional respondents felt that it was necessary to raise awareness in the general public that the energy efficiency and the quality of the indoor environment work together to enhance the performance of passive houses.

Both groups felt that the long-term benefits compensated for the initial costs. The results showed that they would be willing to spend more money on building passive houses to preserve the planet, reduce their carbon footprints, and promote sustainability. This suggests that both groups recognized that green buildings significantly contribute to a healthier planet. Responses about energy cost savings were less frequent due to the participants' lack of experience in residing in passive houses. Although there was a high level of interest in and understanding of passive houses, there was no information about the actual cost savings.

The other responses, including responses from those who were currently residing in passive houses, are as follows.

Comments from Professionals

- "Building codes in Korea are starting to move toward the low-carbon and greengrowth goal. We especially need to go zero-energy buildings by 2030. There are government building energy policies that many public and private sectors are starting to adopt. Energy-efficient construction is gaining traction in Korea."

- "Building regulations these days stress the environmental significance of a building's design, as well as its construction, and various ratings are awarded to those that deal with these the best. Things like insulation properties, passive solar gain, glazing orientation, and material choices are all deemed important and are covered in some depth for us."

- "Most worry about up-front costs; we need to focus more on sustainability and longevity. We are all ready for a positive, conscious change, and these professionals are leading the way. There is always an opportunity for change and growing public awareness."

- "While passive houses do an excellent job of tackling problems associated with gas and energy consumption, they do not address water consumption at all."

Comments from the General Public

- "I want to live in a passive house considering the comfortable indoor environment. I have heard that passive house design endeavors to produce houses that use the least amount of energy while providing a quality indoor environment."

- "I watched a TV documentary on passive houses. To certify one house, testing, adjusting, and commissioning were required. I thought that these procedures would give passive houses more comfortable and healthier indoor environments rather than simply producing the most energy-efficient buildings."

Comments from Passive House Residents from the General Public

- $\quad$ "For me, the comfortable indoor environment was the strongest motivation for moving into a passive house. My passive house technology functioned well with lower energy costs. In particular, during transitioning seasons, when cooling and heating were not needed, the passive house worked better compared to conventional houses." 
- "I am satisfied with the indoor air quality in my passive house because the installed Minimum Efficiency Reporting Values (MERVs) work well in filtering outdoor pollutants associated with vehicular traffic and industrial activities. In particular, the issues of yellow dust and particulate matter in Korea have rapidly increased due to spatial and seasonal conditions; the system refreshes the indoor air without opening windows. My real-time display of the indoor environmental quality shows good performance data."

- "I watched the news about how high ventilation rates will decrease the risk of the airborne spread of COVID-19 in buildings. The ventilation system in residential buildings plays a critically important role for me and my family."

\section{Discussion}

This is the first study to explore the differences between professionals and the general public in terms of passive houses in Korea. Through the survey, we asked respondents to express their perceptions and knowledge regarding passive houses. These are pivotal topics for both the residential market and future Korean Low Carbon and Green Growth policies. It is important to provide evidence that demonstrates the demand for green homes, as this information can draw investments in the low-energy home market. The passive house highlights a commitment to efficiency and an effort to reduce individual energy consumption. It also accrues long-term financial, ecological, social, and health benefits when compared to fossil-fuel-code buildings.

When analyzing the results from the non-professional focus group, it was not expected for them to have detailed knowledge of passive houses in the Korean context, where multi-family residential buildings are dominant and more than $50 \%$ of the population lives in apartments. In Korea, apartments are products that are produced and traded as commodities and that are built and supplied by public and private construction companies, such as Korea Land and Housing Corporation, Samsung C\&T, and Hyundai Development Company. However, the non-professionals that showed interest in passive houses had already acquired a basic level of knowledge, and many of them wanted to know more. Despite the higher expected costs of passive houses, the respondents expressed their desire to live in a passive house. They expected that the additional initial costs would be offset by the quality of the living environment and the monthly savings. According to them, certified passive houses are able to achieve high levels of comfort, as they are well insulated, avoid thermal bridges, and can be a pragmatic investment that lowers costs in the long run.

In the professionals' focus group interview, more detailed professional knowledge was found. For instance, the current Korean building code indicates four climate zones for the whole country. They are the Central 1, Central 2, South, and Jeju Island zones. According to the code, one house in the Central 1 zone needs to have triple glazing and much thicker insulation than one in the Central 2 zone. The Korean code has focused on the U-values, which have improved significantly over the years, but it does not have any requirements for airtightness, and the professionals commented that airtightness is a critical feature. In addition, according to the interview, KPHs are mainly timber-framed houses due to the cost-efficient methods of constructing low-rise buildings. They use local materials and technologies that are already available in the Korean construction market to reduce the embodied energy and achieve the intended efficiency. The professionals wanted to have opportunities to build different types of passive buildings with local products and systems. For this, quality assurance and continual improvement are the prominent factors contributing to the success and credibility of passive houses in Korea.

The results indicated that higher construction costs were still a major barrier for all respondents, and this resulted in the stifling of demand. This phenomenon is common in the adoption of passive technologies. Figure 6 shows a statistically significant difference in expected costs between the professional and public groups' perspectives: The expectations were higher in the public group. However, the costs of passive houses that would be affordable remained around $20-30 \%$ for both groups. There seems to exist a need for more 
education in and distribution of information on Korean Passive Houses among the general public. This would help reduce misconceptions about passive houses' incremental costs, leading to an increase in their market penetration.

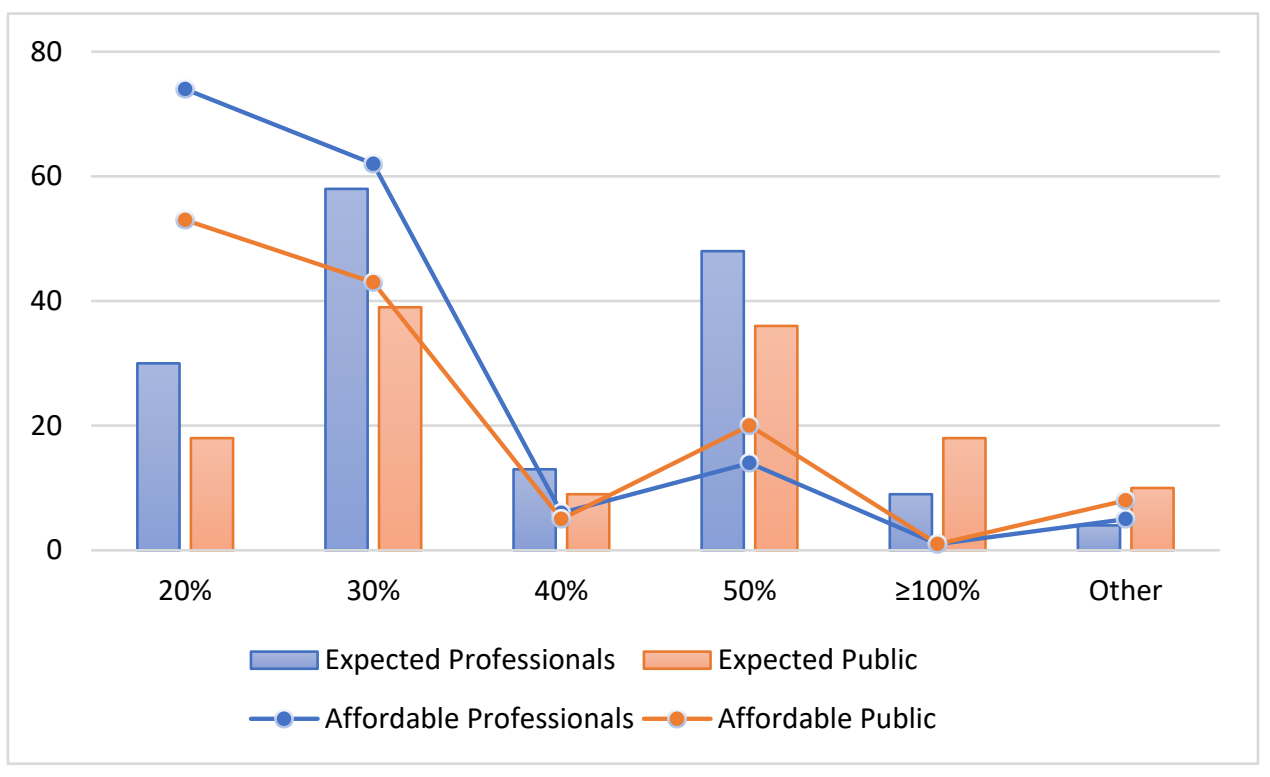

Figure 6. Expected and affordable costs: professionals vs. public.

Professionals need to make an effort to assure the quality of Korean Passive Houses by continually improving the related skills and technologies and localizing the construction materials. According to the PHIKO, there are some cost hurdles and a learning curve, but they predict that those challenges can be overcome in a few years with the growing market (PHIKO, 2017). There has been an ongoing discussion about the expertise of the Korean building industry in properly building passive houses. Specific passive house skills are required when constructing these buildings, and there are a limited number construction specialists who have the experience to properly address the goals of performance criteria. A small group of developers, builders, and architects are now registered as members of the Passive House Institute Korea: 37 architecture companies, 25 construction companies, four engineering companies, five specialists, and 25 product and system companies (PHIKO, 2020). The cost differential between passive and conventional houses is expected to be higher in countries where passive house components are not yet readily available. As passive house components become more available, prices will drop.

Passive house construction costs have recently decreased in Korea. The PHIKO estimates an additional up-front investment of approximately $15-60 \%$ above that of a national-code-compliant house $[57,58]$. Estimates of the cost of a passive house vary depending on the size, style, and how clients go about getting these houses, so they are difficult to confirm. As shown in Figure 7, the cost per square meter of a passive house ranges from USD 1760 to 2437 [57]. Larger projects benefit from economies of scale, but not as much as in the US (3-10\%) and Europe (3-8\%) due to the smaller market $[59,60]$. Some added costs due to triple-paned windows and added insulation may be offset by smaller boilers and smaller heating and air-conditioning systems. In addition, having more familiarity with passive-building methods will reduce the costs of training contractors. Potential construction cost reductions for Korean Passive Houses need to be more openly advertised by actively educating future clients, including those from the general public. The more passive houses we build, the lower the construction costs will be. 


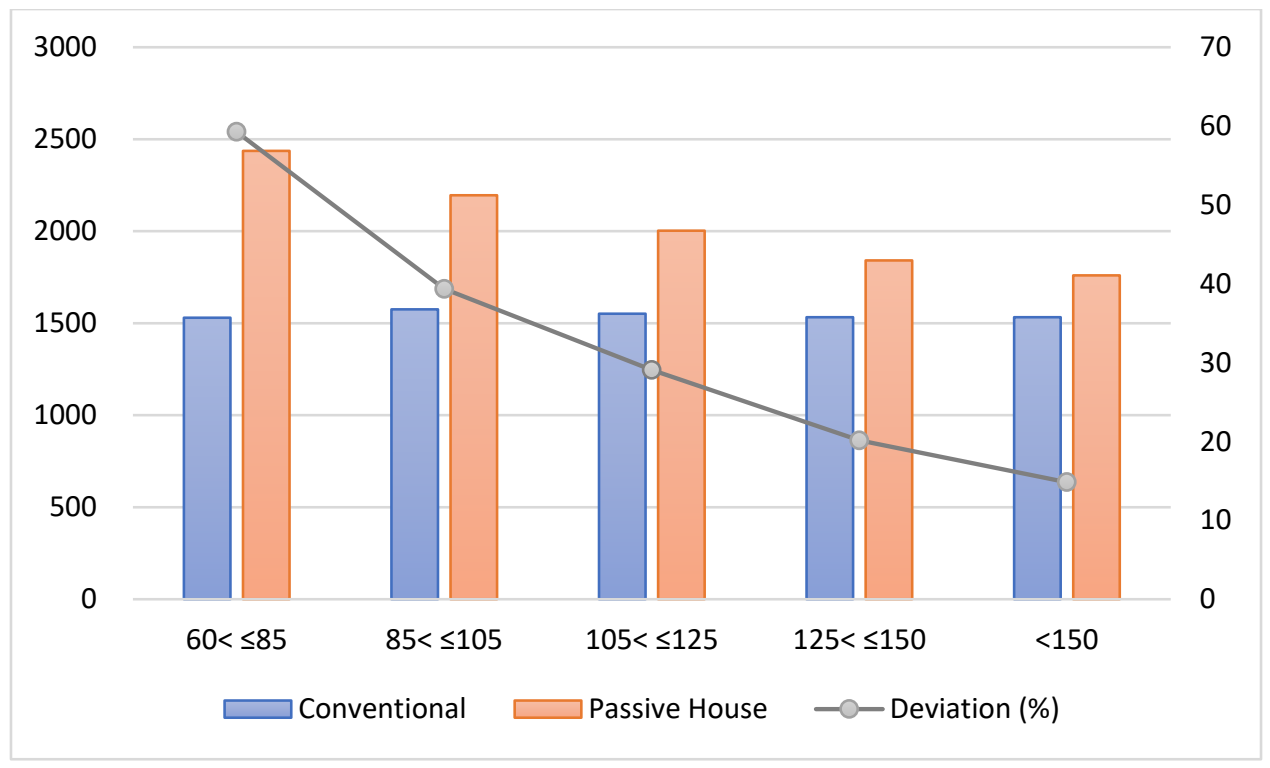

Figure 7. Construction cost by size (USD/m²) (Source: PHIKO and MOLIT).

Though the Korean government's green building policies mainly focus on greening new public and large private buildings, the private sectors have played a voluntary leading role in the implementation of green building with passive houses. The top-down approach to sustainable development and the centralized power of the government need to be in harmony with the private sectors in various fields and industries by providing incentives, sharing technologies, and enlarging the local market. These efforts will greatly support private sectors in reducing the capital costs and increasing the affordability of passive houses with respect to development and construction. Affordability must be addressed in order to encourage the energy efficiency of buildings in private sectors. Building a passive house means near-zero energy costs and high levels of indoor comfort. A combination of economic and environmental sustainability should be sought in order to help accelerate the adoption of passive houses by a wide range of stakeholders.

\section{Conclusions}

The Korean building sector accounts for about $30 \%$ of the national greenhouse gas emissions. Governmental green building certifications and the passive house standard were both designed with the intent of enhancing energy efficiency and indoor environmental quality. Even though governmental green building systems, such as G-SEED, BEER, and ZEBs, have focused mostly on public and multi-family residential buildings, small-sized private buildings, which represent more than $80 \%$ of all buildings in the nation, are far from achieving sustainability. They face challenges in following the green building policies due to limited budgets and relatively small increases in efficiency compared to the up-front costs. However, Korean buildings must achieve nearly zero energy consumption-regardless of size and owners-by 2023. Private green buildings, such as passive houses, can address this goal by pursuing a free economy. Although the rapid development of green buildings in the nation represents the effectiveness of the strong policies, the government needs to support small and private buildings in reaching the goal of sustainability. Education, material and product development, and quality assurance are important, as the interest in passive houses is growing. For example, governments can support the private sector by encouraging the building of passive houses via financial incentives, such as grants and lower interest loans, as well as education.

The expected construction costs of passive houses were perceived to be more expensive by the respondents from the general public. This outcome seems to be related to their prior knowledge. Lacking knowledge on the construction process of passive houses, the general public anticipated a higher level of expected costs, unlike the professionals, who likely had 
a significant level of technical and professional skills and knowledge. Education is essential for bringing changes in the general public's perspectives on passive houses. At the same time, professionals should not stop searching for ways to develop, find, and utilize more reasonably priced building materials, since that would also ensure a broader adoption of passive houses in the Korean market.

The findings of this study suggest that engineers and architects be educated to develop expertise in designing energy-efficient passive houses. Many of the respondents interviewed were students who showed interest in passive houses, but they agreed that their school education was insufficient. Experienced professionals also have limited access to the education on passive houses, except via a limited number of paid seminars by the PHIKO and other institutions. The government could play a key role in establishing education systems at the university level for basic passive-house-related architectural and engineering courses. We recommend that universities create post-graduate or continuing education programs for architects who are already practicing. Education is critical for the current and new generations of architects and engineers.

There is also a need to produce appropriate components for passive houses and to make them easily available on the market by encouraging the industry to produce highquality insulation, ventilation systems, and windows, as well as to conduct research and development $(R \& D)$ programs.

Research is essential in investigating whether the performance and the indoor environmental quality of passive houses function as designed. It is important to monitor actual building performance, including energy consumption, indoor air quality, and thermal comfort. In addition, feedback on end users' perceptions and experiences is needed in order to improve the design and support the intended operations. Although the number of passive houses built in Korea is still very limited, it is important to study end users' perceptions and their experiences in the built environment to verify the effectiveness of passive houses in the local context. Quality assurance and continual improvement are important factors that contribute to the success and credibility of passive houses. By using survey-based studies, researchers can explore passive houses' effectiveness. These efforts will help in promoting energy-efficient buildings for the privately owned small-sized building sector, as well as in supporting national sustainability goals.

The scope of this study is limited in terms of the number and characteristics of the participants, who were recruited at Korean seminars and events about passive houses. The small sample size did not allow full control of all of the variables related to the participants' perceptions of passive houses regarding barriers and potential benefits. We suggest that future studies be conducted with participants from different backgrounds in order to allow more sophisticated multi-level analyses. In addition, the statistical methods used in this study were limited; further research is therefore necessary in order to identify the parameters of the model's sensitivity to outputs. An effort needs to be made to make passive homes more affordable and increase people's and developers' awareness of their benefits. In support of this goal, the findings of this research shed new light on end users' perceptions and ways to explore strategies for spurring the concepts and practices of passive houses.

Author Contributions: Each individual author's contributions are specified as follows. Conceptualization, J.L. and J.C.; methodology, J.L. and M.M.S.; formal analysis, J.L.; investigation, J.L.; writing—original draft preparation, J.L.; writing—review and editing, M.M.S.; Discussion, J.L. and M.M.S. All authors have read and agreed to the published version of the manuscript.

Funding: This research received no external funding.

Institutional Review Board Statement: The study was approved by the Institutional Review Board of Korea National Institute for Bioethics Policy (approval number: P01-201912-22-002 and date of approval: 11 December 2019).

Informed Consent Statement: Informed consent was obtained from all subjects involved in the study. 


\section{Data Availability Statement: Not applicable.}

Conflicts of Interest: The authors declare no conflict of interest.

\section{References}

1. IEA Energy Efficiency. Available online: https://www.nrcan.gc.ca/sites/www.nrcan.gc.ca/files/energy/energy-resources/ Energy_Efficiency_Marketing_Report_2017.pdf (accessed on 1 September 2019).

2. IEA Global Energy \& CO2 Status Report. Available online: https:/ / webstore.iea.org/download/direct/2461?fileName=Global_ Energy_and_CO2_Status_Report_2018.pdf (accessed on 7 November 2019).

3. Climate Transparency the Climate Transparency Report 2020. Available online: https:/ /www.climate-transparency.org/g20climate-performance/the-climate-transparency-report-2020 (accessed on 15 December 2019).

4. KEEI UN FCCC Nat'1 Comm. Available online: http:/ / www.keei.re.kr/main.nsf/index_en.html?open\&p=\%2Fweb_keei\%2Fen_ Issues01.nsf\%2F0\%2FD1D46DE716631EC749256E08000C4561\&s=\%3FOpenDocument\%3D (accessed on 15 December 2019).

5. UN The Paris Agreement. Available online: https://unfccc.int/process-and-meetings/the-paris-agreement/the-paris-agreement (accessed on 11 March 2020).

6. MOE 2nd Master Plan for Response to Climate Change. Available online: http://me.go.kr/home/web/policy_data/read. do? pagerOffset=0\&maxPageItems $=10 \&$ maxIndexPages $=10 \&$ searchKey $=\&$ searchValue $=\&$ menuId=10259\&orgCd=\&condition . deleteYn=N\&seq=7394 (accessed on 15 November 2019).

7. Architecture 2030 Architecture 2030. Available online: https:/ / architecture2030.org/ (accessed on 15 November 2019).

8. USGBC LEED (Leadership in Energy and Environmental Design). Available online: https://new.usgbc.org/leed (accessed on 3 March 2020).

9. NREL The Zero Energy Buildings Resource Hub. Available online: https:// zeroenergy.org/about/ (accessed on 13 March 2020).

10. EU Nearly Zero-Energy Buildings. Available online: https://ec.europa.eu/energy/en/topics/energy-efficiency/energyperformance-of-buildings/nearly-zero-energy-buildings (accessed on 3 March 2020).

11. Office for Government Policy Coordination Framework Act on Low Carbon, Green Growth. Available online: https://elaw.klri. re.kr/kor_service/lawView.do?hseq=49999\&lang=ENG (accessed on 3 March 2020).

12. MOLIT Green Buildings Construction Support Act. Available online: https:/ / elaw.klri.re.kr/kor_service/lawView.do?hseq=5000 8\&lang=ENG (accessed on 22 May 2020).

13. MOLIT Nearly Zero Energy Building. Available online: http://www.molit.go.kr/USR/WPGE0201/m_36421/DTL.jsp (accessed on 22 May 2020).

14. Architecture 2030 Achieving Zero. Available online: https://live-achieving-zero.pantheonsite.io/framework/ (accessed on 19 July 2019).

15. MOLIT Statistics on Buildings. Available online: http:/ / www.molit.go.kr/USR/NEWS/m_71/dtl.jsp?id=95081898 (accessed on 7 July 2020).

16. KEEI A Study on the Building Energy Policy by Analyzing Energy Consumption Factors of Residential Buildings. Available online: http:/ / www.keei.re.kr/web_keei/d_results.nsf/0/8B487340CA0DFABB49258260001B3410/\$file/ (accessed on 19 July 2019).

17. MOLIT \& MOE G-SEED Certified Numbers. Available online: http://gseed.greentogether.go.kr/bcm/odm/selectListOdm.do (accessed on 7 July 2020).

18. MOLIT BEER Certified Numbers. Available online: http://www.molit.go.kr/USR/BORD0201/m_34879/DTL.jsp?id=www_ info\&cate $=\&$ mode $=$ view \&id $x=30420 \&$ key $=\&$ search $=\% E C \% 97 \% 90 \% E B \% 84 \% 88 \% E C \% A 7 \% 80 \% E D \% 9 A \% A 8 \% E C \% 9 C \% A 8$ \%EB\%93\%B1\%EA\%B8\%89\&search_regdate_s=2010-01-01\&search_regdate_e=2019-11-24\&order=\&desc=asc\&srch_prc_stts= \&item_num=0\&search_dept_id=\&search_dept_nm=\&srch_usr_nm=N\&s (accessed on 19 July 2019).

19. MOLIT \& MOE Green Standard for Energy and Environmental Design (G-SEED). Available online: https://elaw.klri.re.kr/kor_ service/lawView.do?hseq=50008\&lang=ENG (accessed on 7 July 2020).

20. Lee, J.; Shepley, M.M.; Choi, J. Exploring the localization process of low energy residential buildings: A case study of Korean passive houses. J. Build. Eng. 2020, 30, 101290. [CrossRef]

21. PHI. About Passive House-What is a Passive House? Available online: https://passivehouse.com/02_informations/01 _whatisapassivehouse/01_whatisapassivehouse.htm (accessed on 22 October 2019).

22. PHI. The Passive House Resources. Available online: https://passipedia.org/ (accessed on 11 January 2020).

23. PHIKO Certified Korean Passive House Statistics. Available online: http://www.phiko.kr/bbs/board.php?bo_table=z3_02 (accessed on 11 January 2020).

24. LH ROREN House (Zero Energy + Rental House). Available online: http://www.rorenhouse.co.kr/index.php (accessed on 3 February 2020).

25. Pitts, A. Passive house and low energy buildings: Barriers and opportunities for future development within UK practice. Sustainability 2017, 9, 272. [CrossRef]

26. Audenaert, A.; De Cleyn, S.H.; Vankerckhove, B. Economic analysis of passive houses and low-energy houses compared with standard houses. Energy Policy 2008, 36, 47-55. [CrossRef]

27. Figueiredo, A.; Figueira, J.; Vicente, R.; Maio, R. Thermal comfort and energy performance: Sensitivity analysis to apply the Passive House concept to the Portuguese climate. Build. Environ. 2016, 103, 276-288. [CrossRef] 
28. Feist, W.; Schnieders, J.; Dorer, V.; Haas, A. Re-inventing air heating: Convenient and comfortable within the frame of the Passive House concept. Energy Build. 2005, 37, 1186-1203. [CrossRef]

29. Mlecnik, E.; Visscher, H.; van Hal, A. Barriers and opportunities for labels for highly energy-efficient houses. Energy Policy 2010, 38, 4592-4603. [CrossRef]

30. Mlecnik, E.; Schütze, T.; Jansen, S.J.T.; De Vries, G.; Visscher, H.J.; Van Hal, A. End-user experiences in nearly zero-energy houses. Energy Build. 2012, 49, 471-478. [CrossRef]

31. PHIUS Climate-Specific Passive Building Standards. Available online: https:/ / www.nrel.gov/docs/fy15osti/64278.pdf (accessed on 11 January 2020).

32. Schnieders, J.; Eian, T.D.; Filippi, M.; Florez, J.; Kaufmann, B.; Pallantzas, S.; Paulsen, M.; Reyes, E.; Micheel, W.; Shih-Chieh, Y. Design and realisation of the Passive House concept in different climate zones. Energy Effic. 2020, 13, 1561-1604. [CrossRef]

33. Foster, J.; Sharpe, T.; Poston, A.; Morgan, C.; Musau, F. Scottish Passive House: Insights into environmental conditions in monitored Passive Houses. Sustainability 2016, 8, 412. [CrossRef]

34. Fernandez-Antolin, M.-M.; del Río, J.M.; Costanzo, V.; Nocera, F.; Gonzalez-Lezcano, A.R. Passive design strategies for residential buildings in different Spanish climate zones. Sustainability 2019, 11, 4816. [CrossRef]

35. Schnieders, J.; Hermelink, A. CEPHEUS results: Measurements and occupants' satisfaction provide evidence for Passive Houses being an option for sustainable building. Energy Policy 2006, 34, 151-171. [CrossRef]

36. Ridley, I.; Clarke, A.; Bere, J.; Altamirano, H.; Lewis, S.; Durdev, M.; Farr, A. The monitored performance of the first new London dwelling certified to the Passive House standard. Energy Build. 2013, 63, 67-78. [CrossRef]

37. RMI. The Economics of Zero-Energy Homes. Available online: https://www.rmi.org/wp-content/uploads/2018/10/RMI_ Economics_of_Zero_Energy_Homes_2018.pdf (accessed on 11 January 2020).

38. DOE Summary of Gaps and Barriers for Implementing Residential Building Energy Efficiency Strategies. Available online: https:/ / www.nrel.gov/docs/fy10osti/49162.pdf (accessed on 21 January 2020).

39. Blomsterberg, Å.; Engvall, K. Overcoming barriers to implementation of very low energy residential buildings in Northern Europe. In Proceedings of the ECEEE 2011 Summer Study: Energy Savings in Buildings, Stockholm, Sweden, 1 July 2011; pp. 1157-1161.

40. EPA. Indoor Air Quality (IAQ). Available online: https://www.epa.gov/indoor-air-quality-iaq/introduction-indoor-air-quality (accessed on 11 January 2020).

41. Kuzman, M.K.; Grošelj, P.; Ayrilmis, N.; Zbašnik-Senegačnik, M. Comparison of passive house construction types using analytic hierarchy process. Energy Build. 2013, 64, 258-263. [CrossRef]

42. Stoyanov, Y. Benefit assessment of passive house in Bulgaria in sustainability context. Manag. Econ. Eng. Agric. Rural Dev. 2018, $18,477-482$.

43. IWBI. Strategies from the Well Being Standard to Support in the Fight Against COVID-19. Available online: https://a.storyblok. com/f/52232/x/f12ca80093/strategiesfromwell-covid19-v2.pdf (accessed on 11 September 2020).

44. USGBC LEED and Indoor Air Quality for Existing Buildings. Available online: https://www.usgbc.org/articles/leed-andindoor-air-quality-existing-buildings (accessed on 23 October 2019).

45. Frontczak, M.; Schiavon, S.; Goins, J.; Arens, E.; Zhang, H.; Wargocki, P. Quantitative relationships between occupant satisfaction and satisfaction aspects of indoor environmental quality and building design. Indoor Air 2012, 22, 119-131. [CrossRef] [PubMed]

46. Arens, E.; Heinzerling, D.; Liu, S.; Paliaga, G.; Pande, A.; Schiavon, S.; Zhai, Y.; Zhang, H. Advances to ASHRAE Standard 55 to encourage more effective building practice. In Proceedings of the Windsor Conference 2020: Resilient Comfort, Windsor, UK, 16-19 April 2020; pp. 1-19.

47. CDC. Unhealthy Air Quality. Available online: https://www.cdc.gov/mmwr/pdf/other/su6001.pdf (accessed on 22 September 2019).

48. József, V. The Ventilation System-There Is No Alternative. Available online: https://passipedia.org/planning/building_services/ ventilation/the_ventilation_system_-_there_is_no_alternative\#the_ventilation_system_there_is_no_alternative (accessed on 23 October 2019).

49. Langer, S.; Bekö, G.; Bloom, E.; Widheden, A.; Ekberg, L. Indoor air quality in passive and conventional new houses in Sweden. Build. Environ. 2015, 93, 92-100. [CrossRef]

50. Crump, D.; Dengel, A.; Swainson, M. Indoor Air Quality in Highly Energy Efficient Homes: A Review; NHBC Foundation: Milton Keynes, UK, 2009; ISBN 9781848061040.

51. Moreno-Rangel, A.; Tim, S.; Gráinne, M.; Filbert, M. Indoor Air Quality in Passivhaus Dwellings: A Literature Review. Int. J. Environ. Res. Public Health 2020, 17, 4749. [CrossRef] [PubMed]

52. DOE. Building America Research-to-Market Plan. Available online: https://www.energy.gov/eere/buildings/downloads/ building-america-program-research-market-plan (accessed on 23 October 2019).

53. Check, J.W.; Schutt, R.K. Research Methods in Education, 1st ed.; SAGE Publications Inc.: Thousand Oaks, CA, USA, 2011; ISBN 978-1412940092.

54. Groat, L.; Wang, D. Architectural Research Methods, 2nd ed.; Wiley: New York, NY, USA, 2013; ISBN 978-0750658515.

55. Yin, R.K. Case Study Research: Design and Methods, 6th ed.; SAGE Publications Inc.: Thousand Oaks, CA, USA, 2017; ISBN 9781506336169.

56. Statistics Korea e-Korea Index. Available online: http:/ / www.index.go.kr/main.do?cate=1 (accessed on 13 January 2020). 
57. PHIKO Passive House Cost. Available online: http:/ / www.phiko.kr/bbs/board.php?bo_table=z3_05\&wr_id=78\#c_186 (accessed on 23 October 2019).

58. MOLIT Construction Cost. Available online: https:// cost.kict.re.kr/\#/notice/file/detail/29663 (accessed on 22 December 2019).

59. iPHA International Passive House Association. Available online: https:/ / www.passivehouse-international.org/ (accessed on 22 December 2019).

60. PHIUS Passive Building Standard Certification Guidebook. Available online: https://www.phius.org/PHIUS+2018/PHIUS+ CertificationGuidebookv2.0_final.pdf (accessed on 22 December 2019). 